\title{
Irfani
}

ISSN 1907-0969 E ISSN 2442-8272

Volume 14 Nomor 2 Desember 2018

Halaman 107-114

http://journal.iaingorontalo.ac.id/index.php/ir

\section{MENCIPTAKAN BUDAYA RELIGIUS DI LINGKUNGAN PENDIDIKAN MELALUI PEMBOBOTAN PERAN PENDIDIK SEBAGAI MAKELAR BUDAYA}

\author{
Momy A.Hunowu \\ IAIN Sultan Amai Gorontalo
}

\begin{abstract}
There are three educational environments namely family, school and community environment. They can create a good generation or a bad generation. It depends on the role of educators. They can create a religious or non-religious environment. The educators are parents, teachers and community leaders. They can act as cultural brokers to protect the generation from the impact of globalization by means of creating religious culture.
\end{abstract}

Keywords: religious culture, educational environments, cultural broker

\section{Pendahuluan}

Masalah kenakalan remaja merupakan masalah yang rumit. Ini semakin ramai terjadi di berbagai kota di Indonesia. Berbanding lurus dengan arus globalisasi dan teknologi yang berkembang pesat, arus informasi yang semakin mudah diakses serta gaya hidup modern. Kenakalan remaja biasanya dilakukan oleh para remaja yang gagal dalam menjalani proses-proses perkembangan jiwanya, baik pada saat remaja maupun pada masa kanak-kanaknya. Kenakalan Remaja, seperti sebuah lingkaran hitam yang tak pernah putus, sambung menyambung dari masa ke masa, dari tahun ke tahun dan bahkan dari hari ke hari semakin rumit dan kompleks. Tindakan kriminalitas yang terjadi di beberapa daerah, awalnya hanya kenakalan remaja yang biasa saja. seiring perkembangan, kenakalan remaja sudah menampakkan pergeseran kualitas kenakalan yang menjurus pada tindak kriminalitas, seperti mencuri, tawuran, membegal, memperkosa bahkan sampai membunuh. Apalagi kecanggihan teknologi informasi dan komunikasi turut mendukung pembentukan generasi yang salah asuh ini, sementara pada bagian lain, para orangtua sibuk mengejar karir dan materi. Sebagai gantinya, banyak orangtua resah gelisah kemudian memilih madsarah dan pesantren untuk menitipkan anak-anaknya, dengan harapan dapat terhindar dari pengaruh negatif di lingkungan sosialnya. Selain itu, juga dapat mengembangkan perilaku yang baik dan terhindar dari kenakalan yang tampak di depan mata. Hal ini terlihat dari semakin menjamurnya sekolah-sekolah Islam terpadu, pondok pesantren dan madrasah seiring semakin membludaknya para pendaftar di lembaga-lembaga pendidikan ini meskipun dibebankan biaya pendidikan dan pembangunan gedung.

Semangat orangtua menyekolahkan anak-anaknya di sekolah unggulan, madrasah dan pesantren patut diberi apresiasi, tetapi jangan sampai lwmbaga-lembaga pendidikan 
itu dianggap sebagai bengkel. Sehingga kemudian menyerahkan semua urusan pendidikan anak pada sekolah. padahal, sekolah hanyalah faktor pendukung, faktor utama adalah keluarga/orangtua.

Tulisan ini akan mengulas tentang bagaimana menciptakan budaya religius, peran pendidik sebagai makelar budaya beserta tantangannya di era globalisasi.

\section{Menciptakan Budaya Religius}

Budaya religius sekolah menurut Dhara (1997) merupakan cara berpikir dan cara bertindak warga sekolah yang didasarkan atas nilai-nilai religius (keberagamaan). Religius menurut Islam adalah melaksanakan ajaran agama secara menyeluruh. Allah berfiman dalam QS. al-Baqarah ayat 208 yang terjemahannya: "Hai orang-orang yang beriman, masuklah kamu ke dalam Islam keseluruhan, dan janganlah kamu turut langkah-langkah syaitan. Sesungguhnya syaitan itu musuh yang nyata bagimu"1.

Agar budaya tersebut menjadi nilai-nilai yang tahan lama, maka harus ada proses internalisasi budaya. Dalam bahasa Inggris, internalized berarti to incorporate in oneself. Jadi, internalisasi berarti proses menanamkan dan menumbuhkembangkan suatu nilai atau budaya menjadi bagian diri (self) orang yang bersangkutan. Penanaman dan penumbuhkembangan nilai tersebut dilakukan melalui berbagai didaktik metodik pendidikan dan pengajaran, seperti pendidikan, pengarahan, indoktrinasi, brain washing dan lain sebagainya. ${ }^{2}$

Sementara Kotter dan James (1997) memberi makna budaya religius dalam konteks organisasi. Dalam suatu organisasi, termasuk lembaga pendidikan, budaya diartikan dalam beberapa definisi. Pertama, sistem nilai, yaitu keyakinan dan tujuan yang dianut bersama yang dimiliki oleh anggota organisasi yang potensial membentuk perilaku mereka dan bertahan lama meskipun sudah terjadi pergantian anggota. Dalam lembaga pendidikan misalnya, budaya ini berupa semangat belajar, cinta kebersihan, mengutamakan kerjasama dan nilai-nilai luhur lainnya. Kedua, norma perilaku, yaitu cara berperilaku yang sudah umum digunakan dalam sebuah organisasi yang bertahan lama karena semua anggotanya mewariskan perilaku tersebut kepada anggota baru. Dalam lembaga pendidikan, perilaku ini antara lain berupa semangat untuk selalu giat belajar, selalu menjaga kebersihan, bertutur sapa santun dan berbagai perilaku mulia lainnya. ${ }^{3}$

Lebih jauh Kotter dan James menjelaskan bahwa dalam organisasi sekolah, pada hakikatnya terjadi interaksi antar individu sesuai dengan peran dan fungsi masing-

\footnotetext{
${ }^{1}$ Kementerian Agama RI. Al-Quran Terjemahan (Bandung: Darus Sunnah, 2015), h.32.

2 Talizhidu Dhara, Budaya Organisasi (Jakarta : Rinike Cipta, 1997), 82.

${ }^{3}$ John P. Kotter dan James L. Heskett, Dampak Budaya Perusahaan Terhadap Kinerja (Jakarta: Perhallindo, 1997), 5
} 
masing untuk mencapai tujuan bersama. Tatanan nilai yang telah dirumuskan dengan baik berusaha diwujudkan dalam berbagai perilaku keseharian melalui proses interaksi yang efektif. Sedemikian rupa sehingga dalam rentang waktu yang panjang, perilaku tersebut akan mewujud dalam bentuk pola budaya tertentu yang unik antara satu organisasi dengan organisasi lainnya. Hal inilah yang pada akhirnya menjadi ciri khas suatu lembaga pendidikan yang sekaligus membedakannya dengan lembaga pendidikan lainnya. Misalnya sekolah memiliki keuinikan berbeda dengan madrasah, madrasah berbeda dengan pesantren. Bahkan ada pula sekolah yang lebih berbudaya religius daripada madrasah dan madrasah yang lebih religius daripada pesantren.

Nilai Budaya religius jika diterjemahkan dapat berwujud semangat berkorban, semangat persaudaraan, semangat saling menolong dan tradisi terpuji lainnya. Sedangkan dalam tataran perilaku, budaya religius dapat berbentuk tradisi salat berjamaah, gemar bersedekah, rajin belajar dan perilaku terpuji lainnya. Dengan demikian, budaya religius sekolah pada dasarnya adalah terinternaliasinya nilai-nilai ajaran agama menjadi suatu kebiasaan dalam berperilaku dan budaya organisasi yang diikuti oleh seluruh warga sekolah. Ajaran agama akan menjadi tradisi manakala warganya mampu menciptakan budaya religius di sekolah. Dengan catatan, budaya religius itu terus ditanamkan dan dipraktikkan setiap saat.

Untuk mewujukan penerapan nilai-nilai religius di sekolah dapat dilakukan dengan beberapa cara, antara lain melalui kebijakan pimpinan sekolah, pelaksanaan kegiatan belajar mengajar di kelas, kegiatan ektrakurikuler di luar kelas dan tradisi serta perilaku warga sekolah secara kontinyu dan konsisten.

Dewasa ini, pihak sekolah, terutama sekolah negeri, berdasarkan kebijakan Menteri Pendidikan dan Kebudayaan sedang giat-giatnya menjalankan program fullday school. Dalam program ini terlihat adanya muatan-muatan budaya religius yang ditekankan agar peserta didik tidak hanya trampil dalam prestasi akademik, tetapi juga memiliki budaya religius yang menjadi pola anutan dalam berperilaku. Sementara sekolah-sekolah swasta tak ketinggalan pula mengembangkan pendidikan karakter, sebagaimana yang dilakukan oleh jaringan sekolah Islam terpadu. Muatanmuatan pengembangan budaya religius mendapat perhatian yang serius.

Namun demikian, upaya-upaya ini diperhadapkan pada berbagai tantangan baik secara internal maupun eksternal. Secara internal, pendidikan dihadapkan kepada keberagaman siswa, baik dari sisi keyakinan beragama maupun keyakinan dalam satu agama. Belum lagi, setiap siswa memiliki latar belakang kehidupan yang berbedabeda. Sementara secara eksternal, gempuran arus globalisasi semakin melumpuhkan peran-peran keluarga dan sekolah. Pemerannya adalah para pendidik baik pendidik formal maupun informal. 


\section{Pendidik sebagai Makelar Budaya}

Pendidik tidak hanya dialamatkan kepada para guru di sekolah, kyai di pesantren, melainkan pula para orangtua dan tokoh masyarakat di lingkungan sosial. Para pendidik ini mestinya dapat berperan sebagai makelar budaya. Pencetus teori makelar budaya adalah Cifford Geertz, dalam penelitiannya, dia menemukan bahwa kyai berperan sebagai alat penyaring atas arus informasi yang masuk ke dalam lingkungan kaum santri, menularkan apa yang dianggap berguna dan membuang apa apa yang dianggap merusak bagi mereka. Namun peranan penyaring itu akan macet manakala arus informasi yang masuk begitu deras dan tidak mungkin lagi disaring oleh sang kyai. Pendapat ini menunjukkan kelemahan kyai dalam memerankan dirinya sebagai makelar budaya. Kehadiran teknologi informasi dan komunikasi dewasa ini benarbenar melemahkan peran kyai sebagai makelar budaya. Sementara menurut Hiroko Horikosi, kyai memiliki karisma karena dipercayai memiliki keunggulan baik secara moral maupun sebagai seorang alim. Selain itu, kyai dapat melakukan inovasi menyesuaikan dengan perkembangan zaman ${ }^{4}$.

Lingkungan pesantren dipercaya masyarakat sebagai lembaga pendidikan yang mapan dalam menginternalisasikan budaya religius, yang mana menurut Wahid (2001) Pesantren adalah sebuah subkultur (sub-culture) dalam pengertian sebagai gejala yang unik, otonom, dan cenderung terpisah dari dunia luar. Labelisasi pesantren sebagai subkultur tidak lepas dari adanya tiga elemen dasar yang melekat dalam kehidupan pesantren, yaitu: (1) cara hidup yang dianut, (2) pandangan hidup dan tata nilai yang diikuti, dan (3) hirarki kekuasaan internal yang ditaati sepenuhnya. ${ }^{5}$

Pandangan bahwa pesantren adalah subkultur juga diperkuat oleh Said Aqil Siraj bahkan menyatakan bahwa selain sebagai "makelar budaya" (cultural broker), pesantren juga berfungsi sebagai "filter budaya" (cultural filter) yang menyaring berbagai unsur luar yang tampak lebih dominan dalam rangka menjamin keutuhan Islam. Karakter seperti inilah yang menjadi alasan kenapa pesantren bisa eksis dalam kurun waktu yang sangat panjang. Namun, karakter itu tidak lantas membuat pesantren bersifat statis. Sepanjang sejarahnya, pesantren memiliki dinamisme yang bersifat adaptatif terhadap kemajuan di luarnya, sejauh tidak berbenturan dengan pandangan hidup dan tata nilai yang diyakini. ${ }^{6}$

\footnotetext{
${ }^{4}$ Hiroko Horikosi, Kyai dan Perubahan Sosial, (Cet. I, Jakarta: Perhimpunan Pengembangan Pesantren, 1987), h. 211.

${ }^{5}$ Abdurrahman Wahid, Menggerakkan Tradisi: Esai-esai Pesantren, cetakan I (Yogyakarta: LKiS, 2001), h. 9-10.

${ }^{6}$ Said Aqil Siraj, Tasawuf sebagai Kritik Sosial: Mengedepankan Islam sebagai Inspirasi, bukan Aspirasi, Cet. I (Bandung: Mizan, 2006), h. 207-209.
} 
Fungsi kyai di pondok pesantren sebagaimana temuan Geertz (1964) sebagai cultural broker dapat diadopsi di sekolah dan keluarga. Guru dan orangtua dapat memposisikan diri sebagai penyaring informasi. Tetapi Gempuran arus informasi yang dibawa teknologi informasi dan komunikasi telah menumbangkan posisi kyai di pesantren, maupun para guru di sekolah dan madrasah. Situsai dan kondisi dewasa ini sebagai akibat kemajuan zaman sudah merubah segalanya. Benteng pertahanan terakhir adalah keluarga. Orangtua baik ayah maupun ibu masih dapat diharapkan untuk menjadi pelopor keselamatan anak-anak. Betapa tidak, durasi waktu yang dimiliki anak lebih lama bersama orangtua. Mulai dari pulang sekolah hingga berangkat lagi ke sekolah. maka rumahtangga adalah ruang kelas yang sangat efektif untuk membentuk karakter anak-anak. Rumah tangga menjadi laboratorium yang dapat diandalkan untuk mengembangkan budaya religius. Keluarga dapat dijadikan sebagai industri anak-anak sholeh. Pertanyaannya, keluarga yang seperti apakah yang diharapkan memenuhi harapan-harapan tersebut di atas?

Sebuah keluarga memiliki struktur ayah sebagai kepala keluarga, ibu sebagai pendidik dan pengayom, anak-anak sebagai peserta didik. Ketiga unsur ini harus dapat memposisikan dirinya dengan benar, lalu didukung dengan kurikulum yang bersumber dari alquran dan hadis. Agar kurikulum berjalan dengan baik, maka fasilitas rumahtangga sebagai ruang belajar harus dihindarkan dari hal-hal yang dapat merusak, misalnya TV, internet dan media lainnya. Bukan berarti mau mengisolir diri dari kemajuan teknologi, tetapi pemanfaatan benda-benda tersebut harus memiliki aturan yang jelas dan pengontrolan yang ketat.

Pendeknya, harus ada sinergi antara lingkungan keluarga, sekolah dan masyarakat. Hal ini sebagaimana dikemukakan oleh Raharja (2013) bahwa pendidikan dalam keluarga menekankan pada kepribadian anak yang bermanfaat dalam model-model untuk hidup yang baik, pendidikan dalam masyarakat cenderung ke hubungan sosial yang bebas, sedang pendidikan di sekolah mengawal dan mengarahkan perkembangan dan pertumbuhan potensi anak yang dibawa dari keluarga maupun masyarakat. Kekuatan pengaruh masing-masing lembaga pendidikan tersebut bervariasi sesuai dengan kuat lemahnya pendidik atau orang dewasa yang berperan di dalamnya. ${ }^{7}$

Orangtua menjadi kunci utama dalam pendidikan anak. Sementara sekolah dan lingkungan sosial hanya memberi bobot bahkan menurunkan bobot terhadap pendidikan dalam keluarga. Hal ini sebagaimana dikatakan Raharja, Pendidikan anak yang utama tidak bisa dilepaskan dari tanggung jawab orang tua. Oleh karena itu orang tualah yang secara serius mengawal pendidikan anak di sekolah maupun

${ }^{7}$ Setya Raharja, Konfigurasi Pendidikan Antara Keluarga, Sekolah, Dan Masyarakat Pengaruhnya Terhadap Kualitas Pendidikan Sekolah Menengah Pertama Di Kabupaten Bantul, (Yogyakarta: UNY, Disertasi, 2013), h. iv 
mengontrol pengaruh-pengaruh dari masyarakat yang mungkin bersifat positif maupun negatif ${ }^{8}$

Tokoh kyai di pondok pesantren, ustadz/ustazah di madrasah dan guru di sekolah juga memiliki peran yang sangat signifikan sebagai yang menjaga anak-anak binaanya dari pengaruh negatif serta mengembangkan akhlak terpuji. Sepanjang hari, mulai sejak pagi hingga pulang sekolah, anak-anak dibiasakan dengan perilaku religius, mulai dari berjabatan tangan dan mencium tangan para guru, murojaah hafalan pada apel pagi, sholat dhuha, membaca doa belajar, sholat dzuhur berjamaah, puasa sunnah senin kamis, berinfaq setiap jumat, membaca asmaul husna sebelum upacara hari senin, setor hafalan setiap pecan, memakai busana muslim/muslimah (menutup aurat) dan memberi batasan pergaulan ikhwan akhwat.

Hal ini sebagaimana dikemukakan Djunaedi bahwa pada era globalisasi seperti saat ini, keberadaan madrasah sebagai lembaga yang menciptakan budaya religius sangat dibutuhkan untuk melawan dampak atau ekses negatif yang ditimbulkan oleh pengaruh budaya asing yaitu materialism, sekularisme dan liberalism, serta isme-isme lain yang mengancam moralitas generasi muda. Ia adalah benteng bagi budaya Barat yang cenderung merusak moral generasi muda, misalkan budaya mabuk-mabukan, budaya pergaulan bebas, budaya berpakaian yang menampakkan sebagian aurat, dan budaya-budaya lainnya yang tidak sesuai dengan ajaran Islam. Dalam hal ini lingkungan pendidikan dijadikan sebagai instrument utama bagi para pendidik dalam perannya sebagai makelar budaya (cultural broker), seperti yang dikemukakan oleh Cliffort Geertz. ${ }^{9}$

\section{Ancaman Arus Informasi dan Tantangan Makelar Budaya}

Lembaga-lembaga pendidikan seperti madrasah dan pondok pesantren, tidak dapat menghindar dari pemanfaatan teknologi informasi dan komunikasi. Akhirnya, masuklah jaringan internet ke pondok pesantren. Jaringan internet boleh disebut sebagai salah satu jaringan yang melemahkan peran guru (kyai). Inilah yang disebut Adib (2013) bahwa ketika sudah mengenal internet, pesantren mau tidak mau berhadapan dengan situasi ini, sehingga predikatnya sebagai "makelar dan filter budaya" selama ini benar-benar mendapatkan ujian yang serius ${ }^{10}$.

Dari pandangan ini dapat dikatakan bahwa peran cultural broker yang dimainkan oleh kyai, guru agama dan para orangtua rupanya meredup sebagai akibat dari dampak globalisasi. Sedemikian rupa, sehingga meskipun mereka dapat menerapkan

\footnotetext{
${ }^{8}$ Ibid.

${ }^{9}$ Mahfud Djunaedi, Paradigma Baru Filsafat Pendidikan Islam, (Jakarta: Kencana, 2017), h.

${ }^{10}$ Muhammad Adib, Ketika Pesantren Berjumpa Dengan Internet: Sebuah Refleksi Dalam Perspektif Cultural Lag, Jurnal Pusaka, Sekolah Tinggi Agama Islam (STAI) Al-Qolam Malang, Volume 1 | No. 1 | September-Desember 2013 | ISSN: 2339-2215 H.3.
} 
budaya religius di lingkungan sekolah/pesantren/madrasah/keluarga, tetapi akan digoyahkan oleh aktivitas santri/peserta didik/anak yang setiap saat bisa mengakses internet. Terutama media sosial. Sehingga peran pendidik tidak bisa berdiri sendiri, karena tantangannya semakin deras.

Massifnya arus informasi yang disajikan oleh internet, apalagi ketika didorong oleh kapitalisasi media digital, berarti bahwa informasi yang diterima oleh masyarakat atau setiap orang bisa merupakan "banjir" informasi. masyarakat informasi, yaitu situasi di mana informasi yang laksana "air bah" itu justru membuat mereka kesulitan mencerna informasi yang diterima sekaligus membangun tata sosial dan budaya yang lebih baik ${ }^{11}$.

Informasi seperti air bah ini tidak bisa dibendung sendirian oleh para pendidik. Maka peran orangtua dan lingkungan sosial sangat penting untuk bahu membahu menjadi makelar budaya. Sebab bisa saja di lingkungan madrasah, pesantren anak-anak tidak bersentuhan dengan internet, tetapi ketika berada di rumah, mereka sangat bebas mengakses internet, tanpa kontrol orangtua. Apalagi orangtua yang sangat sibuk mengejar karir dan materi.

\section{Penutup}

Dari ulasan sebelumnya dapat dikemukakan hal-hal penutup sebagai berikut:

1. Pendidikan Islam kita masih berorientasi pada penguatan kecerdasan kognitif, sehingga pendidikan Islam yang teoretis harus dibudayakan di lingkungan pendidikan. Menciptakan budaya religius adalah mengisi kekosongan aspek psikomotorik dan afektif.

2. Kemajuan teknologi komunikasi dan informasi tidak mungkin bisa dibendung apalagi ditolak maka salah satu upaya yang dapat dilakukan adalah memberi bobot pada peran makelar budaya.

3. Para pendidik (guru, kyai, orangtua, tokoh masyarakat) dalam posisinya sebagai makelar budaya, bukan lagi menyaring informasi, selain arusnya sangat deras, informasi yang masuk bukan lagi melalui proses interaksi sosial, melainkan melalui proses interaksi melalui media informasi dan komunikasi, maka peran makelar budaya adalah menyiapkan mental keimanan yang kokoh sehingga informasi yang masuk tidak memberi efek terhadap perubahan perilaku.

4. Menciptakan budaya religius adalah metode efektif dalam memfilter informasi yang masuk, sehingga anak-anak tetap bersentuhan dengan teknologi tetapi terkontrol secara internal dan eksternal.

\footnotetext{
${ }^{11}$ AG. Eka Wenats Wuryanta, Digitalisasi Masyarakat: Menilik Kekuatan dan Kelemahan Dinamika Era Informasi Digital dan Masyarakat Informasi, Jurnal Ilmu Komunikasi, Volume 1, Nomor 2, Desember 2004, h. 139
} 


\section{DAFTAR PUSTAKA}

Adib, Muhammad, Ketika Pesantren Berjumpa Dengan Internet: Sebuah Refleksi Dalam Perspektif Cultural Lag, Jurnal Pusaka, Sekolah Tinggi Agama Islam (STAI) Al-Qolam Malang, Volume 1 | No. 1 | September-Desember 2013 | ISSN: 2339-2215

Dhara, Talizhidu, Budaya Organisasi, Jakarta : Rinike Cipta, 1997

Djunaedi, Mahfud, Paradigma Baru Filsafat Pendidikan Islam, Jakarta: Kencana, 2017

Horikosi, Hiroko, Kyai dan Perubahan Sosial, Cet. I, Jakarta: Perhimpunan Pengembangan Pesantren, 1987

Kementerian Agama RI. Al-Quran Terjemahan, Bandung: Darus Sunnah, 2015

Kotter, John P. dan James L. Heskett, Dampak Budaya Perusahaan Terhadap Kinerja, Jakarta: Perhallindo, 1997

Raharja, Setya, Konfigurasi Pendidikan Antara Keluarga, Sekolah, Dan Masyarakat Pengaruhnya Terhadap Kualitas Pendidikan Sekolah Menengah Pertama Di Kabupaten Bantul, Yogyakarta: UNY, Disertasi, 2013

Siraj, Said Aqil, Tasawuf sebagai Kritik Sosial: Mengedepankan Islam sebagai Inspirasi, bukan Aspirasi, Cet. I, Bandung: Mizan, 2006

Wahid, Abdurrahman, Menggerakkan Tradisi: Esai-esai Pesantren, cetakan I, Yogyakarta: LKiS, 2001

Wuryanta, AG. Eka Wenats, Digitalisasi Masyarakat: Menilik Kekuatan dan Kelemahan Dinamika Era Informasi Digital dan Masyarakat Informasi, Jurnal Ilmu Komunikasi, Volume 1, Nomor 2, Desember 2004 